\title{
Clinico-histological analysis of non-neoplastic lesions of cervix
}

Dayal Seema ${ }^{1}$

${ }^{\prime}$ Department of Pathology, UPUMS, Saifai, Etawah, Uttar Pradesh, India

\section{Keywords: \\ Cervicitis; \\ Cervix; \\ Histopathology; \\ Hysterectomy}

\begin{abstract}
Background: Cervix from hysterectomy constitutes the majority of gynecological specimens and includes genital infections to invasive carcinoma. These cervical lesions are the source of morbidity and mortality in women. But, there are many benign lesions which appears malignant on gross and microscopy so, misdiagnosed. Hence, clinical and histopathological examination of cervix is required for proper diagnosis and to exclude misdiagnosis.
\end{abstract}

Materials and Methods: This is a retrospective study conducted in Histopathology section of Pathology Department of Rural Institute of Medical Science and Research, Saifai, Etawah (U.P) India from 1 January 2008 to 31 December 2015 on 1544 hysterectomy specimens. Histopathology examination was the diagnostic tool. Cervical pathologies in hysterectomy specimens were evaluated grossly and microscopically and correlated with clinical findings.

Results: Vaginal discharge was the most common clinical complaint (43.00\%), followed by bleeding complaints $(23.38 \%)$. Grossly normal cervix was seen in $(32.51 \%)$ and nabothian follicles were found in $(20.07 \%)$. On histopathology examination, chronic cervicitis was the most common pathology (79.66 $\%)$.

Conclusion: Cervix is site of shades of grey lesions that include cervical dysplasia to malignancy. But majority of cervical pathologies are benign lesions. However, many times benign lesions are misdiagnosed as malignant. Histopathological examination along with clinical findings is mandatory for the early and accurate diagnosis. Health camps along with cervix screening and educational awareness program should be carried out.

\section{Correspondence:}

Dr Seema Dayal , MD

Associate professor Pathology

UPUMS, Saifai, Etawah (U.P) India

Email: seemadayal77@rediffmail.com

ORCID ID: 0000-0001-8282-2507

Reveived : September $5^{\text {th }} 2017$; Accepted : December 21 ${ }^{\text {st }} 2017$; Published : March $30^{\text {th }} 2018$

Citation: Dayal S. Clinico-histological analysis of non-neoplastic lesions of cervix. J Pathol Nep 2018;8:176-9. doi: 10.3126/jpn.v8i1.19453

Copyright: This is an open-access article distributed under the terms of the Creative Commons Attribution 4.0 International License, which permits unrestricted use, distribution, and reproduction in any medium, provided the original author and source are credited.

\section{INTRODUCTION}

The uterus is pyriform in shape and it is divided into body and cervix. Cervix is divided into ectocervix and endocervix. The endocervix is lined by columnar epithelium while the ectocervix is lined by squamous epithelium and the junction of these two at the external os is termed as the squamo-columnar junction. Gynecological specimens form the substantial proportion of the work load in most of the histopathological departments. ${ }^{1}$ The cervix is a target for viral and other carcinogens which may lead to invasive carcinoma. ${ }^{2}$ Infection constitutes one of the most common clinical complaint in gynecologic practice which may be due to constant exposure to the vaginal bacteria. Cervical 


\begin{tabular}{|c|c|}
\hline Clinical complaints & Number (\%) \\
\hline White discharge per vagina & $664(43.0)$ \\
\hline Bleeding complaints & $361(23.4)$ \\
\hline Mass per vagina & $285(18.4)$ \\
\hline $\begin{array}{l}\text { Abdominal distension \& Pelvic } \\
\text { heaviness }\end{array}$ & $114(7.4)$ \\
\hline Pain abdomen & $98(6.3)$ \\
\hline Painful \& frequent maturation & $12(0.8)$ \\
\hline Others & $10(0.6)$ \\
\hline
\end{tabular}

Table 2: Gross findings of cervix on external and cut surface

\begin{tabular}{cc}
\hline Gross findings & Number (\%) \\
\hline Normal cervix & $502(31.5)$ \\
Nabothian follicle & $310(20.0)$ \\
Hypertrophied\& elongated \\
cervix & $225(14.6)$ \\
Epidermatization & $187(12.1)$ \\
Everted cervix & $154(9.9)$ \\
Inverted cervix & $107(6.9)$ \\
Atrophy & $137(8.9)$ \\
Erosion & $67(4.3)$ \\
Ulcer & $29(1.8)$ \\
Cervical Polyp & $53(3.4)$
\end{tabular}

pathologies include inflammatory lesions, pre invasive cervical intra epithelial neoplasia and cervical cancer ${ }^{3}$ whereas tumor like non neoplastic lesions according to the WHO include endocervical hyperplasia, endometriosis, nabothian cysts and endocervical polyps. ${ }^{4}$ Bacterial infection causes squamous metaplasia and this in turn may give rise to squamous cell carcinoma. Cervical cytology continues to have inherent limitations which include non representative sampling of the cervix and transference of cells from collection device to the glass slide. However, a review of cytology slides after biopsy has shown in reduction in the accuracy of the cervical cytology. Histopathological examination of cervical lesion is the single best gold standard test. ${ }^{5}$ The present study was therefore conducted with a objective to know the spectrum of non neoplastic cervical pathologies in hysterectomy specimens and their correlation with clinical findings.

\section{MATERIALS AND METHODS}

This is a retrospective study carried out in histopathology section of Department of Pathology in Rural Institute of Medical Science \& Research Saifai Etawah (U.P) from 1 January 2008 to 31 December 2015. Permission was obtained from institutional ethical committee. Predesigned Performa was filled which included the relevant information regarding patient's age, presenting complaints, age of marriage, parity and history of oral contraceptive use. On clinical examination cervical bleed on touch, fragility, motility, induration of cervical tissue and surrounding tissue was also examined. On Gross cervical examination, length of cervix, inverted and everted cervix, nabothian follicle, epidermidization, polyp, ulcer, erosion were studied. Sections from cervix were taken at 3-4 microns meters. Hematoxylin and Eosin stain was applied, if required, additional sections were also taken. All the relevant data were collected in Microsoft Excel and were analysed

\section{RESULTS}

During the eight years of study (1st January 2008 to 31st December 2015) 1544 cervix were included in study and examined. The specimens included were hysterectomies only. The most common presenting complaint was white discharge per vagina (43.00\%), bleeding complaints (23.38\%), mass per vagina ( $18.45 \%$ ). ( Table 1) Grossly normal Cervix were seen in $31.51 \%(\mathrm{n}=502)$ followed by nabothian follicles ( $\mathrm{n}=310 ; 20.07 \%)$. (Table 2 )

Histopathological changes seen in these cervixes are shown in table 3. As expected chronic cervicitis with or without squamous metaplasia were the most common respectively. Koilocytic changes were seen in 205 (13.3\%) cases. Microglandular hyperplasia was observed in 21 (1.36\%) cases.

\section{DISCUSSION}

The cervix is spindle shaped and measures approximately $2.5 \mathrm{~cm}$ or a little more. Cervix either from hysterectomies continue to form to form major bulk of gynecology specimens that are received in the histopathology department.

Patients with cervical pathologies may be asymptomatic or may present with vaginal discharge, backache, lower abdominal pain and others. ${ }^{1-3,5}$ Vaginal white discharge $(43.00 \%)$ was the main clinical complaint seen with these patients.

On Gross examination normal cervix was seen in (32.51 $\%)$ whereas nabothian follicles were seen in $(20.07 \%)$ cervices. Nabothian cysts are the most common type of cysts of the cervix. They develop with in the transformation zone secondary to squamous metaplasia covering over and obstructing endocervical glands. ${ }^{1}$ Nawachkor ${ }^{6}$ and Pallidy ${ }^{7}$ diagnosed $(3.3 \%),(29.06 \%)$ of nabothian follicle in their studies respectively. On microscopy examination, nabothian follicles are lined by flattened, single layer of mucin producing endocervical epithelium. ${ }^{1}$ Similar findings were seen in the present study.

Prolapse uterus is a common clinical complaint frequently 
Table 3: Histopathological changes of cervical pathologies

\begin{tabular}{lcc}
\hline Histopathology & Number & Percentage \\
\hline Chronic cervicitis & 1230 & $(79.66 \%)$ \\
Squamous metaplasia & 510 & $(33.03 \%)$ \\
\hline $\begin{array}{l}\text { Nabothian follicle } \\
\text { Koilocytosis }\end{array}$ & 395 & $(25.58 \%)$ \\
$\begin{array}{l}\text { Surface keratinization and } \\
\text { hyperplasia }\end{array}$ & 205 & $(13.27 \%)$ \\
$\begin{array}{l}\text { Endocervical polyp } \\
\begin{array}{l}\text { Microglandular endocervi- } \\
\text { cal hyperplasia(MEH) }\end{array}\end{array}$ & 186 & $(12.04 \%)$ \\
\end{tabular}

encountered in gynecological practice. Normally, when a woman strains, there is no descent of the uterus, while in the advanced cases of the prolapse, the cervix of the uterus may be pushed down to the level of the vulva and even seen outside the vulva. In extreme cases, the whole uterus and most of the vaginal wall may be extruded from the vagina. ${ }^{8}$

In India specially in rural population higher incidence and severe degrees of uterine prolapse occur in women, who have delivered at home by dias because patient are made to bear down before full dilation of the cervix when bladder is not empty and also second stage of labour is prolonged with undue stretching of pelvic floor muscle as episiotomy is not employed by the dias. ${ }^{9}$

The surface epithelium of ectocervix in case of uterine prolapse may develop surface keratinization and hyperkeratosis which is called epidermadization. It occurs due to long standing exposure to air and trauma due to tissue dryness. ${ }^{10}$ In the cervix of prolapse uteri, the clinical appearance is usually referred as leukoplakia. Grossly it may present with hypertrophied, elongation and epidermidization whereas histopathologically as hyperplasia and keratinization. In present study hypertrophied and elongated cervix was seen in (14.57\%). Epidermadization was seen in $12.11 \%$, whereas on microscopy examination it was presented as surface keratinization with hyperplasia in 12.04 percent. Hyperplasia with melanin pigment in basal layer was seen in 0.5 percent.

Atrophied cervix occurs usually seen in older female which occurs due to hormonal atrophy. 11 It was seen in 8.8 percent of all the studied cervix. Other gross findings seen in cervix were erosion $(4.43 \%)$ and ulcer $(1.87 \%)$ which may happen due to trauma.

Cervical polyps are rounded to elongated with a smooth or lobulated surface measuring from few millimeters to $2-3 \mathrm{~cm}$, occurs mainly in multiparous women. Polyp constituted $4.46 \%$ of all cervical pathology and majority of women were multiparous. Differential diagnosis of polypoid lesions are endocervical polyp, leiomyoma, adenomyoma, fibroadenoma, carcinoma, sarcoma and secondary carcinoma.1 So, proper evaluation is required to diagnose polyp. In the present study endocervical polyp was seen in $3.43 \%$ cases. Endocervical polyp may be the result of chronic inflammatory changes i.e., "chronic polypoid cervicitis." Microscopically, they showed dilated endocervical glands, which are seen in an edematous inflamed and fibrotic stroma. ${ }^{3}$

Chronic cervicitis was accounting for (79.66\%) of cervical pathologies forming the bulk. Cervix is gateway for reproduction and sexual intercourse. Hence, it can be prone to STI and UTI's during intercourse, conception, pregnancy, delivery and post partum. ${ }^{2}$ Erosion of cervix also refers to as cervical ectropion occur due to cervical tear sustained during child birth. Cervical erosion is a condition in which squamous covering of the vaginal portion of cervix is replaced by columnar epithelium. It is usually associated with chronic cervicitis. Follicular cervicitis is also known as chronic lymphocytic cervicitis; a variant of cervicitis usually seen in menopausal women who is having thinned epithelium having lymphocytes forming germinal centre, plasma cells was seen in 0.97 percent.

Complications of chronic cervicitis are squamous metaplasia and nabothian follicles. Squamous metaplasia was seen in $33.03 \%$ of cervical pathologies studied. The transition between immature and mature squamous metaplasia is known. So, it is important to recognize this histopathologically hence to over diagnose CIN. ${ }^{9,11}$

Chronic cervicitis with koilocyte change of HPV infection was seen in $13.27 \%$ cases. It is important not to confuse the normal basket weave hyperkeratosis with koilocytosis. ${ }^{1}$ Many Studies have proven koilocytosis in association with HIV infection and low CD4 count have predisposed to intra epithelial carcinoma and malignancy. ${ }^{12}$ Hence, correct diagnosis of koilocytosis is must.

Microglandular endocervical hyperplasia (MEH) is a benign proliferation of endocervical glands. It is frequently detected as a incidental findings on a cervical biopsy or a hysterectomy specimen. MEH has been detected up to $27 \%$ of cone biopsy or hysterectomy specimens. It occurs typically in women using oral contraceptive drugs. ${ }^{13}$

\section{CONCLUSION}

Cervical lesions in majority are benign. These lesions cause morbidity and mortality to the affected women. Histopathological examination along with clinical findings is mandatory for the early and accurate diagnosis so as to provide better and early treatment to the patient. Though less, koilocytic changes were seen in the cervix removed for another reasons. Hence, cervical screening program and health awareness program should be carried out regularly. 


\section{Conflict of interest: None}

\section{REFERENCES}

1. Wright C Thomas, Kurman J Robert, Ferenczy Alex. Blaustein's pathology of the female genital tract. 5th ed. New Delhi: Thomson press;2004.p1203.

2. Kumar V, Abbas A, Fausto N. (Eds): Robbins and Cotran Pathologic Basis of Disease. 7th ed., Philadelphia, Elsevier Saunders, 2005. p 1525.

3. Mohan Harsh. The female genital tract. Textbook of pathology. 3rd ed. New Delhi: Jaypee brothers medical publishers; 1998. p897

4. Siimionescu C, Margaritescu CL, Georgescu CV, Mogoanta L, Marinescu AM. Pseudo-tumoral lesions of the cervix. Room J Morphol Embroyal 2005;46:239-47.

5. Mandal AK, Choudhury S. Diseases of female reproductive system. Textbook of pathology 1st ed. NewDelhi: Avichal publisher; 2010. p1454

6. Nwachokor FN, Forae GC. Morphological spectrum of non neoplastic lesions of the uterine cervix in warri, south- south, Niger. J clin pract 2013;16:429-32. Crossref

7. PallipadyA,Illanthody S, Vaidy R, Ahmed Z, Suvarna R, Metkar G.A. Clinico- Morphological spectrum of the non neoplastic lesions of the uterine cervix at AJ hospital, Manglore. Journal of clinical and diagnostic research. 2011;5:546-50.
8. Swamy MN, Chattopadhyay SK. Genital prolapsed. In: Sengupta BS, Chattopadhyay SK, Verma TR, editors. Gynaecology for Postgraduates and Practitioners. 2nd ed. New Delhi, India: Reed Elsevier India Private Ltd; 2007.

9. Padubidri VG, Daftary SN. Shaw's Textbook of Gynaecology.12th ed. New Delhi:chruchill Living stone.2011. p556

10. Dayal S, Nagrath A. Audit on pre invasive and invasive neoplasm of the cervix and associated pathologies among the women with uterine prolapse in rural women of North India. Clinical Cancer investigation Journal 2016;5:110-5. Crossref

11. Anderson MC . The Cervix, excluding cancer. In: Symmers WST editor. Female reproductive system. Systemic pathology. Edingurh: Churchill Livingstone;1991 . 224-56pp

12. Yamada R, Sasagawa $T$,Kirumbi LW, Kingoro A, Karanja DK, Kiptoo M . Human papilloma virus infection and cervical abnormalities in Nairobi, Kenya, are with a high prevelance of HIV infection. J Med Virol . 2008;80:847-55. Crossref

13. Rosai J. Uterus-cervix. Rosai and Ackerman's Textbook of surgical pathology. 9th ed, New Delhi :Elsevier;2004 .1486$511 \mathrm{pp}$. 